\title{
EFFECT OF FEEDING Acacia saligna (LABILL.) H.L. WENDL. ON GOATS STABLED DURING LATE PREGNANCY AND LACTATION
}

\author{
Raúl Meneses R. .* , Yohana Olivares V¹, Milenko Martinoli S. ${ }^{1}$, and Hugo Flores P. ${ }^{2}$
}

Acacia saligna (Labill.) H.L. Wendl. forage is an alternative feed supply for goats during dry periods It was used as feed during pregnancy and lactation to evaluate production response and some blood parameters. Six animals in each group were fed with $0,25,50,75$, and $100 \%$ of acacia as alfalfa (Medicago sativa L.) hay replacement in a completely randomized design. Forage chemical analysis was done to calculate nutrient intake. Blood samples were analyzed for albumin, urea $\mathrm{N}$, globulin, total protein, $\mathrm{Ca}$, and $\mathrm{P}$. Productive parameters were analyzed by ANOVA, Duncan, and regression analyses between acacia and dry matter (DM), crude protein (CP), metabolizable energy (ME), and milk production. Acacia consumption during pregnancy was $65.5 \%$ of control, affected by the consumption of $\mathrm{CP}$, ME intake and body condition $(\mathrm{P}<0.01)$. Body weight showed no change and $25.9 \%$ was the inflection point of the response curve. Birth weight was different for $100 \%$ acacia in the diet $(\mathrm{P}<0.05)$. In lactation $\mathrm{DM}, \mathrm{CP}$, and $\mathrm{ME}$ intake increased $(\mathrm{P}<0.01)$. Body weight and body conditions decreased for groups with $50 \%$ and $25 \%$ acacia. Only urea $\mathrm{N}$ and albumin were affected by inclusion of acacia. Milk production decreased $(\mathrm{P}<0.01)$ with over $50 \%$ acacia. Milk production was $160.2,163.4,128.2,125.9$, and $66.5 \mathrm{~L}$ for $0,25,50,75$, and $100 \%$ of acacia, respectively. Goat diets should not include more than $25 \%$ acacia forage during pregnancy and lactation.

Keys word: Acacia saligna, pregnancy, lactation, milk production, goats, albumins.

$A$ cacia saligna (Labill.) H.L. Wendl . is being studied in various aspects to rehabilitate degraded rangelands, and as a potential fodder to improve livestock feeding in the Coquimbo Region, Chile. By 2005, 10698 ha had been planted along the coast of this region, climbing to 15000 ha between 2005 and 2011 (Cerda, 2007). It is an adapted evergreen species with appropriate characteristics for cultivation in the dry coastal area (Squella et al., 1985; Mora and Meneses, 2003; 2004). Normally farmers use this resource to feed sheep and goats, especially during summer and autumn. They harvest acacia leaves and stems from young and mature trees during the dry season to provide a daily supplement to grazing.

The evaluation of the potential use of this species as supplemental forage for grazing goats during the last third of pregnancy and lactation did not find positive effects on body weight, body condition, and milk production, even though the animals under grazing supplemented with A. saligna consumed more nutrients than the control treatment supplemented with alfalfa (Medicago sativa L.) (Meneses and Flores, 1999). These results were

${ }^{1}$ Instituto de Investigaciones Agropecuarias INIA, Casilla 36 B, La Serena, Chile. "Corresponding author (rmeneses@inia.cl).

${ }^{2}$ Instituto de Investigaciones Agropecuarias INIA, Casilla 43/3, Santiago, Chile.

Received: 20 March 2012

Accepted: 25 September 2012. probably influenced by grazing or the food substitution rate. However, acacia contains $28.9 \mathrm{~g} \mathrm{~kg}^{-1}$ of total tannins, which have anti-nutritive activity in ruminal digestion, decreasing the nutrient value and limiting acacia protein use. Additionally, organic matter and digestible energy nutritive value is affected by total phenol compounds (Ben Salem et al., 2002; Mahipala et al., 2009). Other researchers report even higher values for total acacia phenolics and condensed tannins. This component links dietary protein and make nutrients less digestible in the rumen, limiting microbial growth, amino acid microbial synthesis and reduces the absorption of amino acids in the intestine (Pritchard et al., 1992; Ben Salem et al., 2008). The addition of polyetilenglicol (PEG) to the diet with $A$. saligna increases consumption and production response in goats more than in sheep (Ben Salem et al., 2002; Krebs et al., 2007). PEG forms a compound with tannins allowing protein $\mathrm{N}$ to be metabolized in the rumen, improving digestibility of dry matter, organic matter, and increasing ruminal ammonia and consequently production level.

Producers in the dry zone of Coquimbo Region require low cost supplementary feed to maintain goat and sheep productivity and to avoid losses during the dry season. Acacia saligna, like other shrubs, offers a good alternative.

The objective of this study was to evaluate Acacia saligna as an alfalfa hay replacement forage for goats in confinement during pregnancy and lactation and to analyze blood parameters. 


\section{MATERIALS AND METHODS}

The experiment was conducted from April to October at

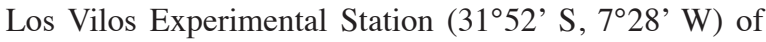
the Instituto de Investigaciones Agropecuarias (INIA). Thirty 2-to-5-yr-old creole goats in individual pens were assigned to five treatments with six replicates. The animals received $0,25,50,75$, and $100 \%$ acacia as an alfalfa hay replacement. The acacia was harvested three times a week from a plantation established in 1977. Samples from this material were collected to determinate leaf, and small $(<4 \mathrm{~mm})$ and large steam $(>4 \mathrm{~mm})$ proportions. The proportion of the acacia component and chemical analyses are shown in Tables 1 and 2. Alfalfa hay and A. saligna forage were offered in pieces and mixed according to the different treatment proportions in an individual feeder at 09:00 and 17:00 h, in amounts resulting in 10\% forage rejection to avoid feed selection. Twice a day, in the morning and afternoon, animals were allowed to walk in a community pen with water. The proportions of forages offered were determined on an intake control basis. Every $3 \mathrm{~d}$ forage samples were obtained from each treatment and every $3 \mathrm{wk}$ these were mixed and dried in an oven at $60{ }^{\circ} \mathrm{C}$ for $62 \mathrm{~h}$ (AOAC, 1990). Dry matter content was determined by drying the sample in the forced-air oven at $105{ }^{\circ} \mathrm{C}$ for $24 \mathrm{~h}$. Crude protein (CP) was obtained as $\mathrm{N}$ by micro-Kjeldahl analysis and then calculated as $6.25 \times \mathrm{N}$ content (AOAC, 1990). Neutral detergent fiber (NDF) and acid detergent fiber (ADF) were measured using a fiber digester (Labconco, USA), and lignin by the $72 \%$ sulfuric acid method (ADL). Hemicellulose was determined from the differences between NDF and ADF and cellulose from the difference between ADF and ADL (van Soest, 1963). Ash was determined by ashing at 550 for $4 \mathrm{~h}$ (AOAC, 1990), and metabolizable energy (ME) was determined by estimating OM digestibility (Tilley and Terry, 1963). Individual intake was calculated as the differences between provided and rejected nutrients.

Table 1. Proportions of Acacia saligna component used during the last third of pregnancy and lactation.

\begin{tabular}{lllll}
\hline & Leaf & Buds & $\begin{array}{c}\text { Thin } \\
\text { stems }\end{array}$ & $\begin{array}{c}\text { Thick } \\
\text { stems }\end{array}$ \\
\hline & & & & \\
\cline { 2 - 3 } & 64.4 & 5.4 & 13.8 & 16.3 \\
Last third of pregnancy & 57.0 & 7.1 & 14.0 & 21.9 \\
\hline
\end{tabular}

Table 2. Chemical composition of Acacia saligna and alfalfa hay.

\begin{tabular}{|c|c|c|c|c|c|c|c|c|c|}
\hline Treatments & $\mathrm{DM}$ & $\mathrm{CP}$ & DMD & NDF & $\mathrm{ADF}$ & Lig & $\mathrm{Cel}$ & Ash & $\mathrm{ME}$ \\
\hline & & & & & & & & & $\begin{array}{c}\text { Mcal } \\
\mathrm{kg}^{-1}\end{array}$ \\
\hline Alfalfa hay & 91.2 & 18.4 & 69.6 & 41.4 & 32.0 & 8.3 & 30.6 & 10.9 & 2.2 \\
\hline Acacia saligna leaf & 91.9 & 16.8 & 46.4 & 40.1 & 28.6 & 8.7 & 19.4 & 9.0 & 1.5 \\
\hline Thin stems & 91.6 & 10.3 & 38.0 & 49.3 & 42.8 & 14.0 & 30.6 & 7.4 & 1.3 \\
\hline Thick stems & 92.5 & 6.7 & 25.9 & 61.8 & 50.5 & 15.2 & 34.8 & 5.0 & 1.0 \\
\hline Buds & 90.2 & 19.9 & 60.7 & 33.3 & 23.5 & 6.6 & 18.0 & 9.2 & 2.0 \\
\hline Weighted & 91.6 & 13.4 & 42.7 & 46.1 & 36.8 & 11.1 & 25.7 & 7.7 & 1.4 \\
\hline
\end{tabular}

DM: dry matter, CP: crude protein, DMD: dry matter digestibility, NDF: neutral detergent fiber, ADF: acid detergent fiber, Lig: lignin; Cel: cellulose, ME: metabolizable energy.
Blood samples were taken by vacutainer from the jugular vein at 40, 70, and $100 \mathrm{~d}$ after kidding. Blood samples were centrifuged for $15 \mathrm{~min}$ to separate serum and then refrigerated. Urea was determined by the by colorimetric method (Fawcett and Scott, 1960). The bromocresol green methodology described by Doumas et al. (1971) was used to determine albumin and blood protein was evaluated by refractometer (Benjamin, 1991). Globulin was obtained from the difference between protein and albumin.

During pregnancy, body weight and conditions were evaluated each $14 \mathrm{~d}$. At kidding, birth type and individual kid body weight was considered, after which body weight conditions were evaluated every $7 \mathrm{~d}$ until day 35 . After that, evaluations were performed every $14 \mathrm{~d}$ until day 101 of lactation. Body conditions were assessed by adapting the methodology described by Russell et al. (1969), which used five levels divided every 0.25 unit, 5 being the maximum value. At birth, kid body weight was evaluated and after that every $7 \mathrm{~d}$. Milk production, and milk samples were taken for total solids (TS) (Pinto and Houbsaken, 1976) and fat matter (FM) PC and lactose were analyzed with MilkoScan 4000 (Foss Analytical, Hillerod, Denmark).

All data were statistically analyzed by an ANOVA and the Duncan test in a complete randomized design (Steel and Torrie, 1980) with the SAS statistic program (SAS Institute, 1989). Regression analyses were performed between Acacia proportions and DM, PC, ME and milk production and to derive the optimal proportion of acacia in the diet. The statistical model used was:

$$
\mathrm{y}_{\mathrm{ij}}=\mu+\delta_{\mathrm{i} 1+} \varepsilon_{\mathrm{ij}}
$$

where: $y_{i j}$ is the observed value of the dependent variable of the replication; $\mu$ is the overall mean of the sample; $\delta_{i 1}$ the treatment effect, and $\varepsilon_{\mathrm{ij}}$ the statistical or random error.

\section{RESULTS AND DISCUSSION}

\section{Last third of pregnancy evaluation}

The A. saligna components and chemical analysis are shown in Tables 1 and 2. Acacia saligna shows lower $\mathrm{CP}, \mathrm{DMD}, \mathrm{ADF}$, cellulose and ME. The acacia chemical composition was similar to that reported by Meneses Flores (1999), who used acacia from the same sources. The values reported by Ben Salem et al. (2002) and Krebs et al. (2007) are also similar to those obtained in the present evaluation. Alfalfa composition was equivalent to the values of the flowering $(\mathrm{NRC}, 1996)$.

DM intake was lower $(\mathrm{P}<0.001)$ in diet with 75 and $100 \%$ acacia, and acacia intake, as the only single, represented $65.53 \%$ of alfalfa intake. PC and ME intake decreased $(\mathrm{P}<0.001)$ inversely to the proportion of acacia in the diet. The cell wall component presented a similar response (Table 3 ) and reached an intake between 41.06 to $50.53 \%$ and 37.19 to $43.58 \%$ for NDF and ADF, respectively. 
Table 3. Daily nutrient intake of goats fed with different proportions of Acacia saligna during late pregnancy.

\begin{tabular}{|c|c|c|c|c|c|c|c|}
\hline $\begin{array}{l}\text { Acacia } \\
\text { saligna }\end{array}$ & $\begin{array}{l}a \\
a\end{array}$ & $\mathrm{CP}$ & NDF & ADF & Cel & Lig & ME \\
\hline$\%$ & \multicolumn{6}{|c|}{$\longrightarrow \mathrm{g} \mathrm{d}^{-1}$} & Mcal d ${ }^{-1}$ \\
\hline 0 & $1872.33 \mathrm{a}$ & $411.19 \mathrm{a}$ & $718.93 \mathrm{c}$ & $533.67 \mathrm{c}$ & $397.70 \mathrm{c}$ & $134.38 \mathrm{c}$ & $4.76 \mathrm{a}$ \\
\hline 25 & $1849.39 \mathrm{a}$ & $366.52 b$ & $759.38 \mathrm{bc}$ & $598.42 b$ & $436.97 b$ & $158.44 \mathrm{~b}$ & $4.19 \mathrm{~b}$ \\
\hline 50 & $1901.72 \mathrm{a}$ & $336.75 \mathrm{c}$ & $845.58 \mathrm{a}$ & $687.88 \mathrm{a}$ & $496.03 \mathrm{a}$ & $187.27 \mathrm{a}$ & $3.62 \mathrm{c}$ \\
\hline 75 & $1718.26 b$ & $270.10 \mathrm{~d}$ & $814.04 \mathrm{ab}$ & $683.66 \mathrm{a}$ & $488.28 \mathrm{a}$ & $190.34 \mathrm{a}$ & $2.74 d$ \\
\hline 100 & $1226.98 \mathrm{c}$ & $167.98 \mathrm{e}$ & $619.95 d$ & $534.73 \mathrm{c}$ & $378.49 \mathrm{c}$ & $151.49 \mathrm{c}$ & $1.58 \mathrm{e}$ \\
\hline $\mathrm{CV}, \%$ & 5.70 & 4.51 & 6.59 & 6.94 & 6.66 & 7.48 & 5.80 \\
\hline $\operatorname{Pr}>\mathrm{F}$ & 0.0001 & 0.0001 & 0.0001 & 0.0001 & 0.0001 & 0.0001 & 0.0001 \\
\hline
\end{tabular}

Means in column with same letters are not different, according to Duncan test $(\mathrm{P}>0.001)$ DM: dry matter, CP: crude protein, NDF: neutral detergent fiber, ADF: acid detergent fiber, Cel: cellulose, Lig: lignin; ME: metabolizable energy, CV: coefficient of variation.

The regression equations are derived from DM intake and acacia percentage in the diet. Equation [1] establishes a maximum inclusion of $28.78 \%$. Although this value does not represent a statistical difference, it is a mathematical limit for the use of acacia. The derivate of the other equations were undetermined.

$$
\mathrm{y}=-0.134 \mathrm{x}^{2}+7.71234 \mathrm{x}+1830.6 \quad \mathrm{r}^{2}=0.9510 \quad \text { [1] }
$$

Body weight evaluation (not included in this report) was not different $(P>0.05)$ among treatments for each date, with a coefficient variation $(\mathrm{CV})$ in the range of $14.49 \%$ to $16.77 \%$. However, CP and ME intake did change. During the treatments, this intake was probably not sufficient to establish significant responses during pregnancy. The body condition (Table 4) presented significant differences $(\mathrm{P}<0.05)$ more consistently from 3 June (day 42 of the evaluation of the last third of pregnancy) due to the inclusion of more than $50 \%$ of acacia. This variable is more sensitive than body weight (Meneses and Flores, 1999), which allows assessing the treatment effect more precisely.

The regression equation derivate for the body condition at kidding (Equation [2]) was $25.97 \%$, limiting this variable at this point, but higher percentages still present statistical equality.

$$
\mathrm{y}=-0.0021 \mathrm{x}^{2}+0.1273 \mathrm{x}+52.809, \quad \mathrm{r}^{2}=0.9632 \quad \text { [2] }
$$

A comparison of nutrient intake and nutrient requirement according to the average body weight and NRC (1981) evidenced an increase in ME deficiency when the acacia percentage increases. The values were $12.36,25.36,42.83$, and $64.10 \%$ for the incorporation of $25,50,75$ and $100 \%$, respectively, of acacia in the diet.

Table 4. Average body condition of goats fed with different proportions of Acacia saligna in the diet during late pregnancy.

\begin{tabular}{lllllll}
\hline & \multicolumn{7}{c}{ Pregnancy evaluation days } \\
\cline { 2 - 5 } $\begin{array}{l}\text { Acacia } \\
\text { saligna }\end{array}$ & $\begin{array}{c}\text { April } \\
\text { A }\end{array}$ & $\begin{array}{c}6 \\
\text { May }\end{array}$ & $\begin{array}{c}20 \\
\text { May }\end{array}$ & $\begin{array}{c}3 \\
\text { June }\end{array}$ & $\begin{array}{c}17 \\
\text { July }\end{array}$ & Kidding \\
\hline$\%$ & & & $\mathrm{~kg}$ & & \\
0 & $2.88 \mathrm{a}$ & $2.58 \mathrm{a}$ & $2.88 \mathrm{a}$ & $2.79 \mathrm{a}$ & $2.83 \mathrm{a}$ & $2.67 \mathrm{a}$ \\
25 & $2.79 \mathrm{a}$ & $2.54 \mathrm{a}$ & $2.58 \mathrm{ab}$ & $2.67 \mathrm{a}$ & $2.63 \mathrm{ab}$ & $2.50 \mathrm{abc}$ \\
50 & $2.71 \mathrm{a}$ & $2.54 \mathrm{a}$ & $2.67 \mathrm{a}$ & $2.58 \mathrm{a}$ & $2.67 \mathrm{ab}$ & $2.58 \mathrm{ab}$ \\
75 & $2.70 \mathrm{a}$ & $2.50 \mathrm{a}$ & $2.54 \mathrm{a}$ & $2.54 \mathrm{ab}$ & $2.46 \mathrm{~b}$ & $2.38 \mathrm{ab}$ \\
100 & $2.83 \mathrm{a}$ & $2.58 \mathrm{a}$ & $2.58 \mathrm{a}$ & $2.38 \mathrm{~b}$ & $2.42 \mathrm{~b}$ & $2.33 \mathrm{c}$ \\
$\mathrm{CV}, \%$ & 6.68 & 8.84 & 9.31 & 8.59 & 8.67 & 7.80 \\
$\operatorname{Pr}>\mathrm{F}$ & 0.4426 & 0.9642 & 0.1678 & 0.0434 & 0.0254 & 0.0170 \\
\hline
\end{tabular}

Means with the same letters on line are not different, Duncan test $(\mathrm{P}>0.05)$. CV: coefficien of variation.
By adjusting $\mathrm{CP}$ intake with the apparent digestibility established by Olivares $(51.77 \%$ evaluated in a parallel work in 2001) the diet deficiency was produced only with the incorporation of 75 and $100 \%$ of acacia in the diet.

Birth weight varied with acacia as the only forage ( $\mathrm{P}$ $<0.05)$ (Table 5). The sex variable was not significant $(\mathrm{P}$ $>0.05$ ). The weights obtained were 2.89 and $3.29 \mathrm{~kg}$ for females and males, respectively. The type of kidding also did not vary $(\mathrm{P}>0.05)$. The values were 3.4, 3.18, and 2.7 $\mathrm{kg}$ for single, twin, and triplet births, respectively.

Although the partial inclusion of acacia produced only a tendency toward lower birth weights, it is necessary to consider nutrient intake reduction; the ME deficit, and the effect on body condition, particularly at birth, which may affect birth weight; and because the type of kidding and sex did not show conclusive results. On the other hand, the phenolic and tannin composition content of acacia (Degen et al., 1995) may reduce nutrient absorption due to fixing, especially of proteins. This led us to conclude that the use of acacia in goat diets during the last third of pregnancy has limitations and that as a consequence of the body condition response, acacia should not be included in percentages higher than $26 \%$ to avoid negative effects on production.

\section{Lactation evaluation}

DM intake during lactation increased $(\mathrm{P}<0.01) 97 \%$ over the control with a high percentage of acacia in the diet (Table 6), which differed from the results during pregnancy. In the latter period, the lower acacia intake can be attributed to the fetus, which reduced abdominal

\begin{tabular}{|c|c|c|c|c|c|}
\hline \multirow{2}{*}{$\begin{array}{l}\text { Acacia } \\
\text { saligna }\end{array}$} & \multicolumn{3}{|c|}{ Type of kidding } & \multicolumn{2}{|c|}{ Goat kid } \\
\hline & Triplets & Twins & Single & Total $\mathrm{N}^{\circ}$ & Weight \\
\hline$\%$ & & & & & $\mathrm{~kg}$ \\
\hline 0 & 1 & 3 & 2 & 11 & $3.4 \mathrm{a}$ \\
\hline 25 & 1 & 4 & 1 & 12 & $3.2 \mathrm{a}$ \\
\hline 50 & 0 & 4 & 2 & 10 & $3.3 \mathrm{a}$ \\
\hline 75 & 0 & 4 & 2 & 10 & $3.3 \mathrm{a}$ \\
\hline 100 & 1 & 4 & 1 & 12 & $2.4 \mathrm{~b}$ \\
\hline $\mathrm{CV}, \%$ & & & & & 17.29 \\
\hline $\operatorname{Pr}>F$ & & & & & 0.011 \\
\hline
\end{tabular}

Table 5 . Birth type and average kid birth body weight $(\mathrm{kg})$.

$\mathrm{CV}$ : coefficient of variation.

Table 6. Lactation nutrient intake of goats offered different proportions

\begin{tabular}{|c|c|c|c|c|c|c|c|}
\hline $\begin{array}{l}\text { Acacia } \\
\text { saligna }\end{array}$ & $\mathrm{DM}$ & $\mathrm{CP}$ & NDF & $\mathrm{ADF}$ & $\mathrm{Cel}$ & Lig & $\mathrm{ME}$ \\
\hline$\%$ & & & & \multicolumn{3}{|c|}{$\mathrm{g}$} & Mcal kg-1 \\
\hline 0 & $1231.5 \mathrm{e}$ & $204.3 d$ & $610.8 d$ & $464.2 \mathrm{e}$ & $305.7 \mathrm{e}$ & $138.5 \mathrm{e}$ & $2.37 \mathrm{e}$ \\
\hline 25 & $1981.4 d$ & $276.7 \mathrm{a}$ & $1048.6 \mathrm{c}$ & $847.5 \mathrm{~d}$ & $585.3 \mathrm{~d}$ & $243.0 \mathrm{~d}$ & $3.34 \mathrm{a}$ \\
\hline 50 & $2171.8 \mathrm{c}$ & $226.7 \mathrm{~b}$ & $1204.2 b$ & $999.3 \mathrm{c}$ & $657.0 \mathrm{c}$ & $302.2 \mathrm{c}$ & $2.91 \mathrm{~b}$ \\
\hline 75 & $2267.2 b$ & $201.8 d$ & $1278.2 \mathrm{a}$ & $1087.1 \mathrm{~b}$ & $741.8 \mathrm{~b}$ & $320.8 \mathrm{~b}$ & $2.59 \mathrm{c}$ \\
\hline 100 & $2434.6 \mathrm{a}$ & $213.8 \mathrm{c}$ & $1295.5 \mathrm{a}$ & $1161.6 a$ & $766.8 \mathrm{a}$ & $365.2 \mathrm{a}$ & $2.45 \mathrm{~d}$ \\
\hline $\mathrm{CV}, \%$ & 8.107 & 12.49 & 8.65 & 8.76 & 10.01 & 9.02 & 9.45 \\
\hline $\operatorname{Pr}>F$ & 0.0001 & 0.0001 & 0.0001 & 0.0001 & 0.0001 & 0.0001 & 10.0001 \\
\hline
\end{tabular}
of Acacia saligna.

Means in column with same letters are not different, Duncan test $(\mathrm{P}<0.001)$. DM: dry matter, CP: crude protein, NDF: neutral detergent fiber, ADF: acid detergent fiber, $\mathrm{Cel}$ : cellulose, Lig: lignin; ME: metabolizable energy, CV: coefficient of variation. 
space, and to the low digestibility of this diet due to $\mathrm{N}$ fixation and ruminal ammonia by tannins, reducing rumen bacterial amino acid synthesis (Ben Salem et al., 2002; 2005; Krebs et al., 2007).

As a consequence of the increased proportion of acacia in the diet, CP and ME intake had the same tendency with $25 \%$ acacia in the diet. However, a higher percentage of acacia, show a decrease in these level which reflects its relative acceptability, evaluated during pregnancy and low digestibility.

The cell wall component had a similar tendency as the percentage of acacia increased. The percentage of NDF and $\mathrm{ADF}$ intake in relation to $\mathrm{DM}$ intake were in the range of 49.6 and $56.4 \%$ and 37.7 and $48.0 \%$ respectively.

The regression equations for diet intake and treatments were:

$\begin{array}{lcc}\text { Dry matter } & \mathrm{y}=-0.144 \mathrm{x}^{2}+25.128 \mathrm{x}+128.9 & \mathrm{r}^{2}=0.9532 \\ \text { Crude protein } & \mathrm{y}=0.0008 \mathrm{x}^{3}-0.1384 \mathrm{x}^{2}+ & \mathrm{r}^{2}=0.9302 \\ & 5.4367 \mathrm{x}+206.24 & \\ \text { Metabolizable } & \mathrm{y}=8 \mathrm{E}-0.6 \mathrm{x}^{3}+0.067 \mathrm{x}+2.3906 & \mathrm{r}^{2}=0.9531 \\ \text { energy } & & \end{array}$

According to the derivates of these equations, the limiting values were 87.4 and $25.1 \%$ for DM and CP. The values of ME were not useful in practical terms.

There was a statistically significant $(P>0.01)$ in urea and albumins content in the blood. Urea decreased with the increase of acacia to $50 \%$ at $40 \mathrm{~d}$ after kidding and in higher percentages at 70 and $100 \mathrm{~d}$ after kidding (Table 7). Albumin showed an inconsistent response. At $40 \mathrm{~d}$ there was an effect with 75 and $100 \%$ of acacia. However, at 70 and $100 \mathrm{~d}$, this effect decreased, while the $75 \%$ treatment presented the lowest albumin level (Table 5). Total protein did not present statistically significant differences $(\mathrm{P}>$ $0.05)$. The levels were between 62.33 and $69.67 \mathrm{~g} \mathrm{~L}^{-1}$.
Globulin levels were also not altered $(\mathrm{P}>0.05)$, the level being between 21.32 and $27.88 \mathrm{~g} \mathrm{~L}^{-1}$. Ca and $\mathrm{P}$ were not affected $(\mathrm{P}>0.05)$ by acacia percentage in the diet. These values were between 2.14 and $2.63 \mathrm{mmol} \mathrm{L}^{-1}$ and 1.79 to $2.7 \mathrm{mmol} \mathrm{L}^{-1}$, respectively. Blood urea $\mathrm{N}$, total protein, and albumin levels were similar to those reported by Fernández et al. (2009) and Ríos et al. (2006).

The partial body weight control did not show a particular response-to any treatment. However the analyses of total daily average weight indicate that body weight increased with 25 and $50 \%$ of acacia, but with the incorporation of $75 \%$ acacia weight decreased (Table 8). Similar results were obtained with the partial body condition, although decreasing as the percentage of acacia in the diet increased. In addition, the average total body condition decreased with $25 \%$ of acacia in the diet (Table 9).

The effect of acacia on nutrient intakes, weight, body condition, urea and albumins blood content was reflected in milk production values, which are shown on Table 10.

Table 7. Urea and albumin blood content of goats fed on different Acacia saligna proportions.

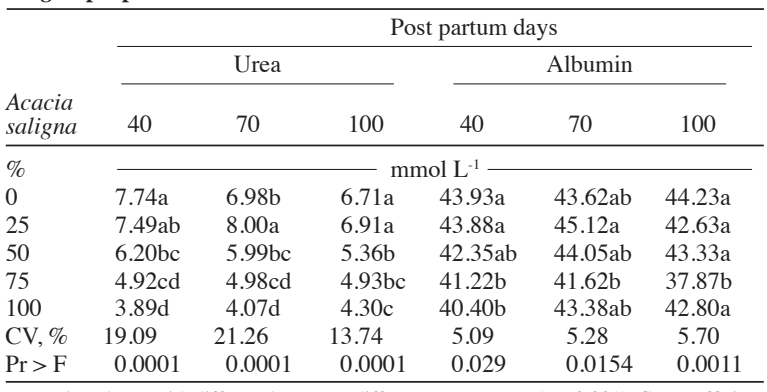

Means in column with different letters are different, Duncan test $(\mathrm{P}<0.001) . \mathrm{CV}$ : coefficient of variation.

Table 8. Partial and total body weight average of goats feeding Acacia saligna on lactation.

\begin{tabular}{|c|c|c|c|c|c|c|c|c|c|c|c|c|c|}
\hline \multirow[b]{2}{*}{$\begin{array}{l}\text { Acacia } \\
\text { saligna }\end{array}$} & \multicolumn{12}{|c|}{ Body weight control on lactation day } & \multirow[b]{2}{*}{$\begin{array}{c}\text { Total } \\
\text { average }\end{array}$} \\
\hline & 1 & 3 & 10 & 17 & 24 & 31 & 38 & 52 & 66 & 80 & 94 & 101 & \\
\hline$\%$ & & & & & & $-\mathrm{k}$ & & & & & & & \\
\hline 0 & 53.2 & $52.0 \mathrm{a}$ & 49.8 & $49.5 \mathrm{a}$ & $50.1 \mathrm{ab}$ & 49.9 & 50.2 & 50.1 & $47.8 \mathrm{ab}$ & $48.2 \mathrm{ab}$ & 47.2 & 46.42 & $49.5 \mathrm{~b}$ \\
\hline 25 & 53.6 & $52.7 \mathrm{a}$ & 50.6 & $49.4 \mathrm{a}$ & $50.2 \mathrm{ab}$ & 49.9 & 49.7 & 49.9 & $49.5 \mathrm{a}$ & $49.2 \mathrm{ab}$ & 48.6 & 46.67 & $50.0 \mathrm{ab}$ \\
\hline 50 & 55.0 & $54.4 \mathrm{a}$ & 50.5 & $50.1 \mathrm{~b}$ & $51.5 \mathrm{a}$ & 50.9 & 50.5 & 51.8 & $50.3 \mathrm{a}$ & $50.7 \mathrm{a}$ & 50.1 & 49.17 & $51.2 \mathrm{a}$ \\
\hline 75 & 51.0 & $51.8 \mathrm{a}$ & 47.2 & $46.8 b$ & 47.6ab & 46.9 & 47.9 & 48.7 & $48.8 \mathrm{ab}$ & 46.1ab & 46.9 & 45.58 & $47.8 \mathrm{c}$ \\
\hline 100 & 49.0 & $46.0 \mathrm{~b}$ & 42.5 & $41.1 \mathrm{c}$ & $40.7 \mathrm{c}$ & 43.3 & 42.7 & 47.2 & $41.3 b$ & $42.2 \mathrm{~b}$ & 42.9 & 42.00 & $42.9 \mathrm{~d}$ \\
\hline $\mathrm{CV}, \%$ & 15.21 & 15.37 & 15.13 & 13.67 & 16.01 & 14.23 & 13.62 & 14.28 & 12.85 & 13.57 & 13.85 & 13.36 & 13.81 \\
\hline $\operatorname{Pr}>F$ & 0.215 & 0.264 & 0.167 & 0.129 & 0.141 & 0.314 & 0.242 & 0.840 & 0.116 & 0.210 & 0.424 & 0.394 & 0.0001 \\
\hline
\end{tabular}

Means in column with different letters are different, Duncan test $(\mathrm{P}<0.001)$. CV: coefficient of variation.

Table 9. Partial and total body condition of goats feeding Acacia saligna on lactation.

\begin{tabular}{|c|c|c|c|c|c|c|c|c|c|c|c|c|c|}
\hline \multirow[b]{2}{*}{$\begin{array}{l}\text { Acacia } \\
\text { saligna }\end{array}$} & \multicolumn{12}{|c|}{ Body weight control on lactation day } & \multirow[b]{2}{*}{$\begin{array}{c}\text { Total } \\
\text { average }\end{array}$} \\
\hline & 1 & 3 & 10 & 17 & 24 & 31 & 38 & 52 & 66 & 80 & 94 & 101 & \\
\hline \multicolumn{14}{|l|}{$\%$} \\
\hline 0 & $2.7 \mathrm{a}$ & 2.6 & 2.6 & $2.7 \mathrm{a}$ & $2.7 \mathrm{a}$ & $2.8 \mathrm{a}$ & $2.9 \mathrm{a}$ & $2.8 \mathrm{a}$ & $2.9 \mathrm{a}$ & $2.8 \mathrm{a}$ & $2.8 \mathrm{a}$ & 2.75 & $2.74 \mathrm{a}$ \\
\hline 25 & $2.5 \mathrm{abc}$ & 2.5 & 2.5 & $2.5 \mathrm{ab}$ & $2.6 \mathrm{a}$ & $2.7 \mathrm{a}$ & $2.7 \mathrm{ab}$ & $2.7 \mathrm{ab}$ & $2.6 \mathrm{ab}$ & $2.7 \mathrm{ab}$ & $2.7 \mathrm{ab}$ & 2.63 & $2.61 b$ \\
\hline 50 & $2.6 \mathrm{ab}$ & 2.5 & 2.5 & $2.5 \mathrm{ab}$ & $2.6 \mathrm{a}$ & $2.7 \mathrm{a}$ & $2.7 \mathrm{ab}$ & $2.5 b$ & $2.7 \mathrm{ab}$ & $2.6 \mathrm{ab}$ & $2.7 \mathrm{ab}$ & 2.75 & $2.62 b$ \\
\hline 75 & $2.4 \mathrm{bc}$ & 2.4 & 2.5 & $2.5 \mathrm{ab}$ & $2.5 \mathrm{ab}$ & $2.5 \mathrm{ab}$ & $2.5 b c$ & $2.5 b$ & $2.4 \mathrm{~b}$ & $2.4 \mathrm{~b}$ & $2.4 \mathrm{~b}$ & 2.42 & $2.44 \mathrm{c}$ \\
\hline 100 & $2.3 c$ & 2.4 & 2.4 & $2.3 b$ & $2.3 \mathrm{~b}$ & $2.3 \mathrm{~b}$ & $2.4 \mathrm{c}$ & $2.4 \mathrm{~b}$ & $2.4 \mathrm{~b}$ & $2.4 \mathrm{~b}$ & $2.4 \mathrm{~b}$ & 2.42 & $2.37 \mathrm{c}$ \\
\hline $\mathrm{CV}, \%$ & 7.72 & 8.87 & 8.33 & 7.52 & 7.36 & 8.86 & 8.10 & 9.00 & 10.05 & 9.15 & 9.35 & 9.87 & 2.54 \\
\hline $\operatorname{Pr}>\mathrm{F}$ & 0.023 & 0.433 & 0.320 & 0.076 & 0.012 & 0.023 & 0.003 & 0.031 & 0.018 & 0.043 & 0.068 & 0.062 & 0.0001 \\
\hline
\end{tabular}

Means in column with different letters are different, Duncan test $(\mathrm{P}<0.001) . \mathrm{CV}$ : coefficient of variation. 
Table 10. Milk production of goats feeding different proportions of Acacia saligna.

\begin{tabular}{ccccccccc}
\hline & \multicolumn{9}{c}{ Acacia saligna Diet, \% } & & CV \\
\cline { 2 - 7 } & 0 & 25 & 50 & 75 & 100 & $\operatorname{Pr}>$ F & $\%$ \\
\hline Milk production, L & $160.2 \mathrm{a}$ & $163.4 \mathrm{a}$ & $128.2 \mathrm{~b}$ & $125.9 \mathrm{~b}$ & $66.5 \mathrm{c}$ & 0.0001 & 15.4 \\
\hline
\end{tabular}

The milk production for 0 and $25 \%$ treatments were the same but different from those for the other treatments, which were $160.24,163.35,128.18,125.92$, and $66.48 \mathrm{~L}$ respectively for the $0,25,50,75$ and $100 \%$ treatments. The 50 and $75 \%$ treatments were the same different from the $100 \%$ treatment. The variation coefficient was $15.35 \%$ and the significance level was lower than $5 \%$.

The regression made for the treatments and milk production was polynomial $(\mathrm{P}<0.05)$ and the equation resulted in:

$$
y=-0.0105 x^{2}+0.1538 x+160.65 \quad r^{2}=0.9329
$$

The derived calculation establishes a maximum value of $7.32 \%$ of acacia in the diet. Milk component TS, FM, $\mathrm{CP}$, and lactose were not statistically affected by the inclusion of acacia in the diet.

The evaluation of the last third of pregnancy showed that acacia could not be included in percentages higher than $26 \%$ to avoid limiting production. As our results from the last third of pregnancy lsuggest and as reported by Meneses and Flores (1999), body conditions appear to be more sensitive than body weight according to statistical analyses. In this case, body condition is the variable that most limits the inclusion of acacia, to a proportion of $25 \%$ during the milking period, although the derivative of the equation for lactation is even lower.

The higher nutrient intake evaluated during lactation did not necessarily result in higher production, which could be attributed to the effect of incorporating $A$. saligna on the digestibility of the diet. According to Ben Salem et al. (2002; 2008), acacia has tannin components that decrease the digestibility of protein due to nitrogen fixation. Moreover, acacia in goat diets decreases urea and albumin levels in the blood, indicating their excretion. Ruminal ammonia is in equilibrium with ammonia and associated with blood urea synthesis in the liver. As well, protein availability decreases for rumen microorganisms and absorption of protein by the animal. Although there are no precise values, it is possible that feeding with only acacia over an extended period would produce a negative nitrogen balance. The results obtained indicate there is an effect on all of the evaluated variables but at different levels of inclusion of acacia in the dietand there is a maximum level without any effect on productive variables, as shown in the present document.

\section{CONCLUSION}

Acacia saligna fodder has limitations as feed for goats. In pregnancy its acceptability as the only forage, represented $65 \%$ of that of alfalfa hay, but during lactation the intake was higher than alfalfa hay. Blood urea is affected with $50 \%$ of acacia inclusion. The response of albumin is inconsistent and the other blood components did not present effects from consuming acacia. However, acacia should not represent more than $26 \%$ of diet during the last third of pregnancy, according to body weight, conditions and birth weight. During lactation, acacia should not represent more than $25 \%$ to avoid affecting milk production, although the regression equation determined that it should not represent more than $7.3 \%$. A higher percentage in the diet would affect animal productivity and more than $50 \%$ would affect body weight. Maximum DM intake is obtained with $24.8 \%$ of acacia in the diet.

Efecto de la alimentación con Acacia saligna (Labill.) H.L. Wendl. en caprinos estabulados en el último tercio de preñez y lactancia. La Acacia saligna es una alternativa de alimentación para caprinos, por lo que se ofreció a hembras en preñez y lactancia para evaluar su respuesta y algunos parámetros sanguíneos. Los animales fueron asignados a grupos que recibieron $0,25,50$, 75 y $100 \%$ de acacia en reemplazo de heno de alfalfa (Medicago sativa L.), en un diseño completamente al azar. Análisis químico de forraje fue realizado para calcular consumo de nutrientes. Albumina, $\mathrm{N}$ úrico, globulinas, proteína total, $\mathrm{Ca}$, y $\mathrm{P}$ fueron analizados en sangre. Se controló peso, condición corporal, y peso de nacimiento. Se realizó ANDEVA, Duncan, y regresión para acacia y las variables evaluadas. El consumo de acacia en la preñez fue $65,5 \%$ del control, afectó el consumo de proteína cruda (PC), energía metabolizable (EM) y condición corporal $(\mathrm{P}<0,01)$. El peso corporal no fue afectado ( $\mathrm{P}<0,01)$, siendo 25,9\% el nivel límite de inclusión de acacia. El peso de nacimiento fue diferente con $100 \%$ de acacia $(\mathrm{P}<0,05)$. En lactancia, el consumo de MS, PC, y EM aumentó $(\mathrm{P}<0,01)$. Niveles de 50 y $25 \%$ acacia disminuyeron el peso y la condición corporal. El $\mathrm{N}$ úrico y albumina fueron afectados por la acacia. La producción de leche disminuyó $(\mathrm{P}<0,01)$ con niveles superiores a $50 \%$, obteniéndose 160,$2 ; 163,4 ; 128,2 ; 125,9 ;$ y 66,5 L con $0,25,50,75$ y $100 \%$ de acacia, respectivamente. La acacia no debe incorporarse en niveles mayores a $25 \%$ en dietas de caprinos en preñez y lactancia.

Palabras clave: Acacia saligna, preñez, lactancia, producción de leche, caprinos, albumina.

\section{LITERATURE CITED}

AOAC. 1990. Official method of analyses. 134 p. $15^{\text {th }}$ ed. Association of Official Analytical Chemists (AOAC), Arlington, Virginia, USA.

Cerda, J. 2007. Reseña y futuro del sector forestal en la Región de Coquimbo. Ciencia e Investigación Forestal. Número Extraordinario. p. 47-58. Silvicultura y utilización de especies del género Acacia. 
Benjamín, M. 1991. Manual de patología clínica en veterinaria. 1311 p. $3^{\mathrm{a}}$ ed. Ed. Limusa, Ciudad de México, México.

Ben Salem, H., H. Abdouli, A. Nefzaoui, A. El-Mastouri, and L. Ben Salem. 2005. Nutritive value, behaviour, and growth of Barbarine lambs fed on oldman saltbush (Atriplex nummularia L.) and supplemented or not with barley grains or spineless cactus (Opuntia ficus-indica f. inermis) pads. Small Ruminant Research 59:229-237.

Ben Salem, H., N. Atti, A. Priolo, and A. Nefzaoui. 2002. Polyethylene glycol in concentrate or feedblocks to deactivate condensed tannins in Acacia cyanophylla Lindl. foliage. 1. Effects on intake, digestion and growth by Barbarine lambs. Animal Science 75:127-135.

Ben Salem, H., A. Priolo, and P. Morand-Fehr. 2008. Beneficial and detrimental effects of dietary condensed tannins for sustainable sheep and goat production- Progress and challenges. Animal Feed Science and Technology 147:116-139.

Doumas, B., A. Waston, and W. Biggs. 1971. Albumin standards and the measurement of serum albumin with bromocresol green. Clinical Chemistry Acta 31:87-97.

Degen, A., K. Becker, H. Makkar, and N. Borowy. 1995. Acacia saligna as a fodder tree for desert livestock and the interaction of its tannins with fibre fractions. Journal of the Science of Food and Agriculture 68:65-71.

Fawcett, J.K., and J.E. Scott. 1960 A rapid and precise method for the determination of urea. Journal of Clinical Pathology 13:156164.

Fernández, C., C. Mata, O. Piquer, F. Bacha, and J.M. de la Fuente. 2009. Influence of betaine on goat milk yield and blood metabolites. Tropical and Subtropical Agroecosystems 11:209213.

Krebs, G.L., D.M. Howard, and K. Dods. 2007. Feeding Acacia saligna to sheep and goats with or without the addition of urea or polyethylene glycol. Asian Australasian Journal of Animal Sciences 20:1551-1556.

Mahipala, M.B., G.L. Krebs, P. McCafferty, and L.H. Gunaratne. 2009. Chemical composition, biological effects of tannin and in vitro nutritive value of selected browse species grown in the West Australian Mediterranean environment. Animal Feed Science and Technology 153:203-215.

Meneses, R., y H. Flores. 1999. Evaluación de caprinos de reemplazo y adultos en el último tercio de preñez y lactancia alimentados con Acacia saligna. Agricultura Técnica (Chile) 59:26-24.
Mora, F., y R. Meneses. 2004. Comportamiento de procedencias de Acacia saligna (Labill.) H.L. Wendl. en la Región de Coquimbo, Chile. Ciencia Forestal Santa María 9:103-109.

Mora, F., y R. Meneses. 2003. Efecto del riego sobre el crecimiento y producción forrajera de Acacia saligna (Labill.) H.L. Wendl. en la zona árida de Chile. CERNE 9:257-260.

NRC. 1981. Nutrient requirements of domestic animals. Nutrient requirements of goats. $\mathrm{N}^{\circ} 15.91 \mathrm{p}$. National Research Council (NRC), National Academy Press, Washington, D.C., USA.

NRC. 1996. Nutrient requirements of domestic animals. Nutrient requirements of beef cattle. 234 p. $7^{\text {a }}$ ed. National Research Council (NRC), National Academy Press Washington, D.C., USA.

Pinto, M., y A. Houbsaken. 1976. Métodos de análisis químico de leche y productos lácteos. 345 p. FAO, Centro Tecnológico de la Leche para Chile y América Latina, Valdivia, Chile.

Pritchard, D.A., P.R. Martin, and P.K. O'Rourke. 1992. The role of condensed tannins in the Nutritive value of Mulga (Acacia aneura) for sheep. Australian Journal of Agricultural Research 49:1739-1746

Ríos, C., M. Marín, M. Catafau, y F. Wittwer. 2006. Concentraciones sanguíneas de B-hidroxibutirato, NEFA, colesterol y urea en cabras lecheras de tres rebaños con sistemas intensivos de producción y su relación con el balance nutricional. Archivos de Medicina Veterinaria 38:19-23.

Russel, A.F., J.M. Doney, and R.G. Gunn. 1969. Subjective assessment of body fat in live sheep. Journal of Agriculture Science 72:451-454.

SAS Institute. 1989. User's guide version 6.2846 p. $4^{\text {th }}$ ed. SAS Institute, Cary, North Carolina, USA

Squella, F., R. Meneses, y T. Gutiérrez. 1985. Evaluación de especies forrajeras arbustivas bajo condiciones de clima mediterráneo árido. Agricultura Técnica (Chile) 45:303-313

Steel, H., and H. Torrie. 1980. Principles and procedure of statistic: A biometrical approach. 481 p. $2^{\text {nd }}$ ed. McGraw-Hill Book, New York, USA.

Tilley, T., and R.A. Terry. 1963. A two stage techniques for the in vitro digestion of forage crops. Journal of British Grassland Society 18:104-111.

Van Soest, P. 1963. Use detergent in the analysis of fibrous feeds. II. A rapid method for the determination of fiber and lignin. Journal Association Official Agriculture Chemistry 46:829-834. 